International Journal of Pure and Applied Mathematics

Volume 109 No. 1 2016, 3-7

ISSN: 1311-8080 (printed version); ISSN: 1314-3395 (on-line version)

url: http://www.ijpam.eu

doi: 10.12732 /ijpam.v109i1.2

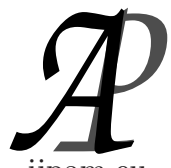

ijpam.eu

\title{
DRUMI BAINOV: THE WORK AND LIFE (IN MEMORIAM)
}

\author{
Mihail M. Konstantinov ${ }^{1}$, Snezhana G. Hristova ${ }^{2}$ \\ ${ }^{1}$ University of Architecture, Civil Engineering and Geodesy \\ Sofia, BULGARIA \\ ${ }^{2}$ Plovdiv University "Paisii Hilendarski" \\ Plovdiv, BULGARIA
}

Drumi Dimitrov Bainov (July 2, 1933 - July 1, 2011) was born in Sofia, Bulgaria. He graduated from the Sofia University in 1957 majoring in "Mathematics". In 1966 he received a PhD from the Moscow State University. From 1972 he is an Associate Professor, and from 1989 - a Full Professor in Mathematics in Bulgaria. He is a Doctor Honoris Causa of the Plovdiv University "Paisii Hilendarski", Bulgaria. His life had been dedicated to science and education in Mathematics.

Professor Drumi Bainov is the most productive Bulgarian Mathematician and one of the most successful pedagogues in this country. He is the author of 12 monographs issued by prestigious publishing companies. In addition, he has published more than 830 scientific papers in national and international scientific journals. The monographs and articles written by Prof. Bainov are cited more than 12500 times, or in other words, he has been cited approximately in 107 sources annually (according to "Harzin'g Publish and Perish" and based on Google Scholar ${ }^{\mathrm{TM}}$ database (as of 2016)). The list of his monographs is given in the references at the end of this note in a chronological order. Drumi Bainov has an incredible ability to work in a team having published with more than 50 co-authors.

Received: August 1, 2016

Published: September 1, 2016 (c) 2016 Academic Publications, Ltd. url: www.acadpubl.eu 
The research interests of D. Bainov include, but are not limited to, initial value problems and boundary value problems for differential equations, functional differential equations and integro-differential equations. In particular he has substantial contributions to the following general subject areas for equations of the above mentioned types:

- General theory

- Qualitative theory

- Stability theory

- Oscillation theory

- Small parameter methods

- Averaging theory

- Superneutral equations with iterated delay

- Equations with impulses

- Equations with maximums

- Mechanics and optimal control

- Modeling in economics, chemistry and biology

Using the Mathematical Subject Classification 2010 it may be observed that Drumi Bainov has worked intensively in the following particular areas: $34 \mathrm{~A} 12$, 34A37, 34A45, 34B05, 34B08, 34B10, 34B37, 34C10, 34C25, 34C29, 34D05, 34D10, 34D20, 34E10, 34G20, 34H15, 34K05, 34K07, 34K10, 34K11, 34K13, $34 \mathrm{~K} 20,34 \mathrm{~K} 33,34 \mathrm{~K} 35,34 \mathrm{~K} 40,34 \mathrm{~K} 45$ as well as 39B62, 45J05, 92C45, 92C50 and $97-\mathrm{XX}$.

It should also be noted that Prof. D. Bainov as, a famous Mathematician, is one of the influential contributors into the area of Impulsive Differential Equations. In the early 80 -s he created the Bulgarian group of Mathematicians working in differential equations with impulses. In addition, many international researchers from all over the World joined to this group. This group has been published (and continues to publish) more than 1000 papers in the area of impulsive differential equations. 
Prof. D. Bainov had been a lecturer of many mathematical disciplines in several Bulgarian Universities and he is author of several mathematical textbooks. He was an advisor of 29 (twenty nine) PhD students in Mathematics from Bulgaria and other countries who successfully defended their theses. Most of them are now Associate Professors and Full Professors. This remarkable number - $29 \mathrm{PhD}$ students, shows the breadth of mathematical ideas and imagination that Prof. D. Bainov possessed.

Prof. D. Bainov was the main organizer of many international colloquia and conferences. Among them are the Colloquia listed below that were held in Plovdiv, Bulgaria:

- International Colloquium on Numerical Analysis and Computer Science with Applications with 12 editions in the period 1991-2002;

- International Colloquium on Differential Equations with 12 editions in the period 1989-2000;

- International Colloquium on Applied Mathematics and Computing with 5 editions in the period 2004-2008.

Drumi Bainov had been the Editor in Chief of the following scientific journals:

- Communications in Applied Analysis (CAA), ISSN 1083-2564, Dynamic Publishers Inc., Atlanta, GA 30362, USA

- International Journal of Pure and Applied Mathematics (IJPAM), ISSN 1311-8080, Academic Publications Ltd.

- International Journal of Differential Equations and Applications (IJDEA), ISSN 1311-2872, Academic Publications Ltd.

- International Journal of Computational and Numerical Analysis and Applications (IJCNAA), ISSN 1311-6789, Academic Publications Ltd.

- International Electronic Journal of Pure and Applied Mathematics (IeJPAM), ISSN 1314-0744, Academic Publications Ltd.

Drumi Bainov also placed huge personal efforts in the initial phases of establishing these journals. He is the founder of the journals IJDEA, IJCNAA, IJPAM, IeJPAM, mentioned above. In addition, Prof. D. Bainov had been 
a member of the Editorial boards of another 18 international Mathematical journals.

Some of the remarkable characteristics of Bainov's scientific research are summarized in Table 1 (Data is taken from Google Scholar ${ }^{\mathrm{TM}}$ (similar results may be obtained using the mathematical database MathSciNet) and other databases).

\begin{tabular}{||c|c||}
\hline \hline Monographs & 12 \\
\hline Papers & 826 \\
\hline Papers spotted by Google & 562 \\
\hline Cited papers spotted by Google & 380 \\
\hline Citations & 10096 \\
\hline h-index & 29 \\
\hline g-index & 95 \\
\hline hc-index & 12 \\
\hline hI, norm & 18 \\
\hline Cites per scientific work & 18 \\
\hline Maximum citations per monograph & 4491 \\
\hline \hline
\end{tabular}

Table 1: Scientometric data for Prof. D. Bainov

It is worth mentioning that the monograph [3] is cited more than 4000 times (!) which is a rare event for a mathematical book. Of course, some of the recorded citations are self-citations, however the number is negligible.

The excellent scientometric indicators presented at Table 1 show that Prof. D. Bainov is ranked very highly in the scale of modern mathematicians. He is, by no doubt, the most productive Mathematician and one of the best teachers of Mathematics in Bulgaria.

Note that (as of 2009) there were nine Mathematicians with more than 500 published papers: 1. Paul Erdös with 1585, 2. Drumi Bainov with 837, 3. Saharon Shelah with 826, 4. Hari Srivastava with 803, 5. Leonard Carlitz with 743, 6. Lucien Godeaux with 669, 7. Yuri Mitropolskii with 608, 8. Frank Harary with 593, and 9. Richard Bellman with 554.

Unfortunately, we lost our friend and teacher, Professor Drumi Bainov, five years ago. His ideas, however, are still vital and we are happy to elaborate of them in our research and teaching endeavors.

We end this short note with the list of monographs of Prof. D. Bainov. We note that for some of the items there may be more than one ISBN since there 
have been reprints.

\section{References}

[1] D. Bainov, M. Konstantinov (1973). The Averaging Method and its Application to Technique. "Nauka i Izkustvo" Publ. House, Sofia (in Bulgarian), MR 0330567, ZMATH 291.34033, $1255 / 77$.

[2] D. Bainov, P. Simeonov (1989). Systems with Impulse Effect. Stability, Theory and Applications. Ellis Horwood Ser. Math. Appl., Ellis Horwood Ltd, Chichester, Halsted Press, New York, 1989, ISBN 0-7458-0457-8.

[3] V. Lakshmikantham, D. Bainov, P. Simeonov (1989). Theory of Impulsive Differential Equations. Ser. Modern. Appl. Math. 6, World Sci. Publ. Co., Teaneck, New Jersey, ISBN 978-9971-5-0970-5.

[4] D. Bainov, D. Mishev (1991). Oscillation Theory for Neutral Differential Equations with Delay. Adam Hilger, Bristol, ISBN 0-7503-0142-2.

[5] D. Bainov, P. Simeonov (1992). Integral Inequalities and Applications. Kluwer Acad. Publ., Dordrecht, 1992, published also by Springer-Science + Business Media, Dordrecht, ISBN 978-9048-14154-8.

[6] D. Bainov, P. Simeonov (1993). Impulsive Differential Equations: Periodic Solutions and Applications. Pitman Monogr. Surveys Pure Appl. Math. 66. Longmann Scientific\&Technical, Essex, Great Britain, ISBN 0-5820-9639-1.

[7] D. Bainov, V. Covachev (1994). Impulsive Differential Equations with a Small Parameter. Ser. Adv. Math. Appl. Sci. 24, World Sci. Publ. Co., River Edge, NJ, ISBN 978-981450401-0.

[8] D. Bainov, D. Mishev (1995). Oscillation Theory of Operator-Differential Equations. Ser. Soviet East Europ. Math. 10, World Sci. Publ. Co., River Edge, NJ, ISBN 978-981021100-4.

[9] D. Bainov, P. Simeonov (1995). Impulsive Differential Equations: Asymptotic Properties of the Solutions. Ser. Adv. Math. Appl. Sci. 28, World Sci. Publ. Co., River Edge, NJ, ISBN 978-9814-50188-0.

[10] D. Bainov, S. Kostadinov (1996). Abstract Imulsive Differential Equations. Descartes Press, Koriyama, ISBN 978-4925-04311-3.

[11] D. Bainov, P. Simeonov (1998). Oscillation Theory of Impulsive Differential Equations. International Publ., Orlando, FL.

[12] D. Bainov, S. Hristova (2011). Differential Equations with Maxima. Chapman\&Hall/CRC Pure Appl. Math., ISBN 978-1439-86757-0. 
